\title{
Domains and Standards of School Leadership: Evaluation of Tertiary School Teachers
}

\author{
Angelo R. Santos, mBA; Rita L. Cajucom, Ph. D
}

$\mathrm{Ph}$. DBA Candidate in Nueva Ecija University of Science and Technology, Instructor, College of Management and Business Technology, Nueva Ecija University of Science and Technology, Philippines

Professor, College of Education, Nueva Ecija University of Science and Technology, Philippines

\begin{abstract}
School Leaders are modifiers of teaching and learning, crucial to maintaining good teachers and necessary for improving educational standards. This study described Standards of School Leadership in terms of: Leading Learning and Teaching Domain, Leading School Development Domain, Organizational Management Domain, and Professional Growth and Development Domain. The descriptive method of research was used in this study. A total of 107 tertiary school teachers which have permanent appointment or considered as regular employee for more than 3 years were surveyed around Nueva Ecija. After analyses of data, the following conclusions were formulated: first, domains of school leadership can be viewed from leading learning and teaching, leading school development, organizational management, and professional growth and development. Second, among these domains, organizational management was found to be the focus of school leaders. Third, school leaders create a culture of professional learning that fosters continuous improvement in learning, teaching and assessment. Fourth, school leaders engage in a continuous process of evidence-based school self-evaluation. Fifth, ensure the safe functioning of the school on a day-to-day basis. Last, school leaders recognize the need to manage workload to ensure a sustainable work/life balance. The researchers want to recommend some matters based from the formulated conclusions. It is indeed noticeable that organizational management is the main focus of the school leaders thus, it is recommended that school leaders should not let other domains of school leadership be taken for granted. Continuous harnessing on the strengths based on the standards is highly recommended. On the others hand, strengthening of the following is also recommended: school leaders should foster a commitment to inclusion and equality of opportunity of each student; promote communication within the school and manage challenging and complex situations and build professional networks with other school leaders.
\end{abstract}

Keywords - School Leader, School Leadership, School Development, Leading Domain, Teaching Domain.

\section{INTRODUCTION}

School Leaders are modifiers of teaching and learning, crucial to maintaining good teachers and necessary for improving educational standards. Standards are a rallying point for the articulation of ethical principles and values, and are instruments that can continually be used to make judgments on school leaders ' results (Ingvarson et al., 2006). Leaders will demonstrate the same leadership characteristics that teachers expect: openness to new ideas, ability to be motivated by performance and flexibility in the face of challenge (Lashway, 2002).

In order to keep pace with the current developments, an academic leader should attend conferences, lectures and workshops; further education would make her more informed and confident in the execution of her duties (Santos \& Garcia, 2020).

Thus, it is necessary to identify what should be similar to a set of standards of school leadership, or basic aspects of good school leadership activities, regardless of where school leaders work (Ingvarson, 2006).

A school leader steers and promotes the institution's staff and job processes as the quality of education and school leadership are strongly linked (Bal \& de Long, 2007). Certain important aspects of school leadership were described as aligning curriculum with established expectations, setting educational targets for student performance, evaluating progress against 
those goals and making adjustments to improve performance in the school program (Schleicher, 2012).

\section{CONCEPTUAL FRAMEWORK}

School leadership plays a key role in enhancing school performance by shaping teachers ' motives and abilities, as well as the atmosphere and community they work in, if considered efficient, it increases schooling productivity and equity (Pont et al., 2008).

Effective school leaders are active advocates of professional development, fostering the creation of professional communities and guiding school organizations to adhere to common values (Murphy et al., 2007).

On the contrary, the conservative standards system mistakenly views the principal as primarily responsible for a multitude of activities that could and should be reconsidered in terms of school administration rather than from a school leader viewpoint (Pitre \& Smith, 2004).

\section{OBJECTIVES OF THE STUDY}

This study described Standards of School Leadership in terms of: Leading Learning and Teaching Domain, Leading School Development Domain, Organizational Management Domain, and Professional Growth and Development Domain.

\section{METHODOLOGY}

The descriptive method of research was used in this study because it involves description, recording, analysis and interpretation of condition that really exists. It is appropriate to use descriptive method in gathering information about the present existing condition (Creswell, 2014). A total of 107 tertiary school teachers which have permanent appointment or considered as regular employee for more than 3 years were surveyed around Nueva Ecija.

The researchers distributed survey questionnaires which adapted Likert-scale type responses (Vagias, 2006) and analyzed it through statistical data treatment such as mean and weighted mean.

\section{RESULTS AND DISCUSSIONS}

Table 1. Leading Learning and Teaching Domain and Standards of School Leadership

\begin{tabular}{|c|c|c|}
\hline Our school leader/s... & Mean & $\begin{array}{c}\text { Verbal } \\
\text { Interpretation }\end{array}$ \\
\hline $\begin{array}{l}\text { 1. create a culture of professional learning that fosters continuous improvement in learning, } \\
\text { teaching and assessment }\end{array}$ & 3.43 & Strongly Agree \\
\hline 2. foster the development of the full range of teacher competencies & 3.12 & Agree \\
\hline 3. foster a commitment to inclusion and equality of opportunity of each student & 2.50 & Agree \\
\hline 4. develop and implement a system to promote professional responsibility and accountability & 2.54 & Agree \\
\hline 5. manage the design, planning and implementation of the school curriculum & 3.29 & Strongly Agree \\
\hline Average Mean & 2.98 & Agree \\
\hline
\end{tabular}

Legend Verbal Interpretation (VI)

$\begin{array}{cc}3.25-4.00 & \text { Strongly Agree } \\ 2.50-3.24 & \text { Agree } \\ 1.75-2.49 & \text { Disagree } \\ 1.00-1.74 & \text { Strongly Disagree }\end{array}$

It shows on Table 1 that the leading learning and teaching domain of school leaders in tertiary schools got an average of 2.98 with a verbal description of 'agree'. To state a few of its standards, these were their school leaders create a culture of professional learning that fosters continuous improvement in learning, teaching and assessment $(M=3.43$; $V I=$ strongly 
agree) and they also manage the design, planning and implementation of the school curriculum $(M=3.29, V I=$ strongly agree). This finding implies that tertiary school leaders are on hand and in support in creating and managing their school's curriculum and improvement of professional learning in the school.

Table 2. Leading School Development Domain and Standards of School Leadership

\begin{tabular}{|c|c|c|}
\hline Our school leader/s... & Mean & $\begin{array}{c}\text { Verbal } \\
\text { Interpretation }\end{array}$ \\
\hline 1. establish and communicate a guiding mission and vision for the school & 2.56 & Agree \\
\hline 2. engage in a continuous process of evidence-based school self-evaluation & 3.31 & Strongly Agree \\
\hline $\begin{array}{l}\text { 3. build and maintain relationships with parents, other schools, relevant agencies, and the } \\
\text { wider school community }\end{array}$ & 2.78 & Agree \\
\hline 4. promote communication within the school and manage challenging and complex situations & 2.53 & Agree \\
\hline $\begin{array}{l}\text { 5. manage and lead change to respond to the evolving needs of the school and the changing } \\
\text { educational environment }\end{array}$ & 3.30 & Strongly Agree \\
\hline Average Mean & 2.89 & Agree \\
\hline
\end{tabular}

Legend Verbal Interpretation

$\begin{array}{cc}3.25-4.00 & \text { Strongly Agree } \\ 2.50-3.24 & \text { Agree } \\ 1.75-2.49 & \text { Disagree } \\ 1.00-1.74 & \text { Strongly Disagree }\end{array}$

The finding with regards to leading school development domain, as shown in Table 2, of school leadership shows an average mean of 2.89 (verbal interpretation = 'agree'). This domain highlights the standards, particularly, school leaders engage in a continuous process of evidence-based school selfevaluation $(M=3.31 ; V I=$ strongly agree $)$ and they also

Table 3. Organizational Management Domain and Standards of School Leadership manage and lead change to respond to the evolving needs of the school and the changing educational environment $(M=$ 3.30; VI = strongly agree). This suggests that school leaders maintain their involvement for the continuous changing on the evolving needs in light of the academic process.

\begin{tabular}{|c|c|c|}
\hline Our school leader/s... & Mean & $\begin{array}{c}\text { Verbal } \\
\text { Interpretation }\end{array}$ \\
\hline $\begin{array}{l}\text { 1. manage human and physical resources and organizational structures and strategies to create } \\
\text { and maintain a learning organization }\end{array}$ & 3.32 & Strongly Agree \\
\hline $\begin{array}{l}\text { 2. foster ethical standards, implement the values of the school and demonstrate equality, } \\
\text { fairness and justice for all }\end{array}$ & 2.67 & Agree \\
\hline $\begin{array}{l}\text { 4. encourage and facilitate the development of communities of practice in the area of } \\
\text { management and leadership }\end{array}$ & 2.93 & Agree \\
\hline 5. ensure the safe functioning of the school on a day-to-day basis & 3.45 & Strongly Agree \\
\hline Average Mean & 3.12 & Agree \\
\hline
\end{tabular}




\section{Legend Verbal Interpretation (VI)}

$3.25-4.00 \quad$ Strongly Agree

$2.50-3.24 \quad$ Agree

$1.75-2.49 \quad$ Disagree

$1.00-1.74 \quad$ Strongly Disagree

Table 3 presents the organizational management domain of school leadership. Based on the result, this domain got an average mean of 3.12 with a verbal interpretation of 'agree'. Its standards illustrate that school leaders ensure the safe functioning of the school on a day-to-day basis $(M=3.45$; $V I$ $=$ 'strongly agree'), they manage human and physical resources and organizational structures and strategies to create and maintain a learning organization $(M=3.32$; $V I=$ 'strongly agree') and, also, school leaders maintain a climate of security and well-being that enables and supports learning $(M=3.25 ; V I=$ 'strongly agree'). These findings imply that school leaders in terms of their organizational management, they lead and manage the school effectively.

Table 4. Professional Growth and Development Domain and Standards of School Leadership

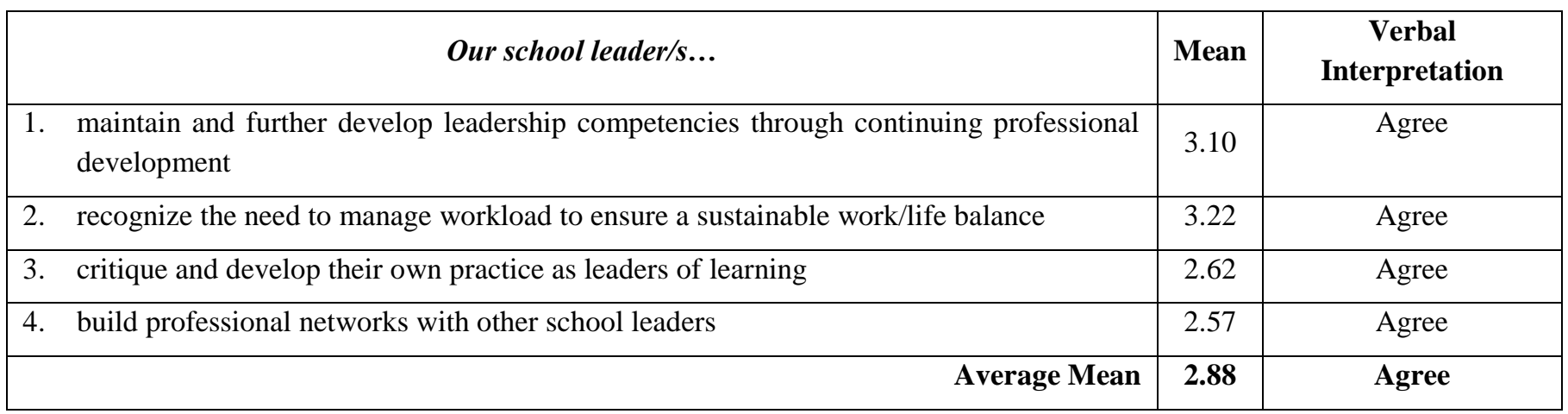

Legend Verbal Interpretation (VI)

$3.25-4.00 \quad$ Strongly Agree

2.50-3.24 Agree

$1.75-2.49 \quad$ Disagree

$1.00-1.74 \quad$ Strongly Disagree

Table 4 shows that the findings with regards to professional growth and development domain of school leadership got an average mean of 2.88 (VI = 'agree'). The standards for this domain show that school leaders recognize the need to manage workload to ensure a sustainable work/life balance $(M=3.22$;
$V I=$ 'agree') and they also maintain and further develop leadership competencies through continuing professional development ( $M=3.10$; $V I=$ 'agree'). This suggests that they seek to apply the understanding they acquire in a meaningful way to their practice on school leaders.

Table 5. Domains of School Leadership

\begin{tabular}{|ll|c|c|c|}
\hline & Mean & Verbal Interpretation & Rank \\
\hline 1. & Leading Learning and Teaching & 2.98 & Agree & Agree \\
\hline 2. & Leading School Development & 2.89 & Agree & 1 \\
\hline 3. $\quad$ Organizational Management & 3.12 & Agree & 4 \\
\hline 4. $\quad$ Professional Growth and Development & 2.88 & & 4 \\
\hline
\end{tabular}




\section{Legend Verbal Interpretation (VI)}

$\begin{array}{cc}3.25-4.00 & \text { Strongly Agree } \\ 2.50-3.24 & \text { Agree } \\ 1.75-2.49 & \text { Disagree } \\ 1.00-1.74 & \text { Strongly Disagree }\end{array}$

Table 5 shows the ranking of domains of school leadership. First in rank is the organizational management $(M=3.12$; $V I$ = 'agree'), second is leading learning and teaching $(M=2.98$; $V I=$ 'agree') and, on third and last respectively are leading school development $(M=2.89 ; \mathrm{VI}=$ 'agree') and professional growth and development $(M=2.88$; VI = 'agree'). The ranking result suggests that school leaders focus most on the organizational management.

\section{CONCLUSIONS AND DISCUSSIONS}

After analyses of data, the following conclusions were formulated: first, domains of school leadership can be viewed from leading learning and teaching, leading school development, organizational management, and professional growth and development. Second, among these domains, organizational management was found to be the focus of school leaders. Third, school leaders create a culture of professional learning that fosters continuous improvement in learning, teaching and assessment. Fourth, school leaders engage in a continuous process of evidence-based school selfevaluation. Fifth, ensure the safe functioning of the school on a day-to-day basis. Last, school leaders recognize the need to manage workload to ensure a sustainable work/life balance.

The researchers want to recommend some matters based from the formulated conclusions. It is indeed noticeable that organizational management is the main focus of the school leaders thus, it is recommended that school leaders should not let other domains of school leadership be taken for granted. Continuous harnessing on the strengths based on the standards is highly recommended. On the others hand, strengthening of the following is also recommended: school leaders should foster a commitment to inclusion and equality of opportunity of each student; promote communication within the school and manage challenging and complex situations and build professional networks with other school leaders.

\section{REFERENCES}

[1] Bal, J., \& de Jong, J. (2007). improving school leadership-oEcD review, Background report for the netherlands. prepared for the Ministry of Education, Culture and Science, Netherlands, available at www. oecd. org/edu/schoolleadership.

[2] Creswell, J. W. (2014). A concise introduction to mixed methods research. SAGE publications.

[3] Ingvarson, L. (2006). Standards for school leadership. Research Developments, 16(16), 4.

[4] Ingvarson, L., Anderson, M., Gronn, P., \& Jackson, A. (2006). Standards for school leadership: A critical review of the literature.

[5] Lashway, L. (2002). Developing Instructional Leaders. ERIC Digest.

[6] Murphy, J., Elliott, S. N., Goldring, E., \& Porter, A. C. (2007). Leadership for learning: A research-based model and taxonomy of behaviors. School leadership and management, 27(2), 179201.

[7] Pitre, P., \& Smith, W. (2004). ISLLC Standards and school leadership: Who's leading this band. Teachers College Record, 10(10), 2004.

[8] Pont, B., Nusche, D., \& Moorman, H. (2008). Improving school leadership, Volume 1: Policy and practice. Australia: OECD Publications. Available online also at: https://www. oecd. org/edu/school/44374889. pdf [accessed in Makassar, Indonesia: October 9, 2016].

[9] Santos, K. E. S., \& Garcia, M. C. (2020). Perceptions of Neust Instructors, Deans and Directors toward Leadership Capabilities. International Journal of English Literature and Social Sciences (IJELS), 5(1).

[10] Schleicher, A. (2012). Preparing teachers and developing school leaders for the 21st century: Lessons from around the world. OECD Publishing. 2, rue Andre Pascal, F-75775 Paris Cedex 16, France.

[11] Vagias, W. M. (2006). Likert-type scale response anchors. clemson international institute for tourism. \& Research Development, Department of Parks, Recreation and Tourism Management, Clemson University. 